\title{
Penyuluhan Kesehatan : Panduan Penggunaan Obat Tradisional yang Benar dan Aman
}

\author{
Wahyu Tusi Wardani \\ Prodi Farmasi, STIKES Surya Global \\ Email : tusy.wardani@gmail.com
}

\begin{abstract}
Abstrak
Masyarakat Indonesia masih percaya pada obat tradisional. Hal itu bisa dilihat dari masih banyaknya penjual berbagai produk obat tradisional yang beredar di pasaran. Sementara itu, gaya hidup sehat yang berkembang saat ini mengarahkan masyarakat untuk kembali menggunakan produk yang berasal dari alam. Oleh karenanya, obat tradisional dapat menjadi salah satu pilihan pengobatan. Melalui kegiatan pengabdian masyarakat ini, diharapkan terjadi peningkatan pengetahuan masyarakat tentang cara penggunaan obat tradisional yang benar dan aman serta masyarakat dapat melakukan swamedikasi obat tradisional dengan benar dan rasional. Metode yang digunakan dalam penyuluhan ini adalah ceramah dan tanya jawab, menggunakan media slide power point yang berisi penjelasan mengenai panduan penggunaan obat tradisional yang benar dan aman. Peserta penyuluhan kesehatan terdiri dari ibu ibu jama'ah pengajian Masjid Baiturrahman Bantulan, Caturtunggal, Depok, Sleman, Yogyakarta dan pengunjung pameran Islamic Book Fair. Kegiatan ini dilaksanakan pada hari sabtu Tanggal 3 Agustus 2019. Pukul 09.00 - 11.30. Tempat pelaksanaan di Panggung Utama Islamic Book Fair, GOR Universitas Negeri Yogyakarta. Peserta yang hadir ada 61 orang. Peserta cukup antusias pada waktu tanya jawab, karena terkait dengan pengalaman penggunaan obat tradisional. Sebelum narasumber memulai menyampaikan materi, nara sumber terlebih dahulu menanyakan ke peserta tentang kebiasaan penggunaan obat tradisional. Ternyata masih ada sebagian kecil kebiasaan yang tidak sesuai dengan pedoman penggunaan obat tradisional yang benar dan aman. Hasil dari pengabdian ini, diketahui pada saat tanya jawab, terlihat kalau peserta sudah meningkat pengetahuannya tentang cara penggunaan obat tradisional yang benar dan aman. Narasumber melakukan tanya jawab untuk melihat pemahaman peserta. Mereka semakin mengetahui pedoman dalam mengkonsumsi obat tradisional. Kesimpulan dari penyuluhan ini, bahwa kegiatan penyuluhan kesehatan tentang panduan penggunaan obat tradisional dapat meningkatkan pengetahuan masyarakat tentang cara penggunaan obat tradisional yang benar.
\end{abstract}

Kata kunci : penyuluhan, kesehatan, obat, tradisional

\begin{abstract}
Indonesian people still believe in traditional medicine. This can be seen from the number of sellers of various traditional medicine products on the market. Meanwhile, the current healthy lifestyle has led people to return using products derived from nature. Therefore, traditional medicine can be one of the treatment options. Through this community service activity, it is hoped that there will be an increase in public knowledge about how to use traditional medicines properly and safely and that people can selfmedicate traditional medicines properly and rationally. The methods were lecture and discussion. The participants of health counseling consisted of members of Baiturrahman Mosque recitation and visitors of Islamic Book Fair exhibition. This activity was held on Saturday, August 3, 2019. 09.00 - 11.30. The venue for the main stage of the Islamic Book Fair, Yogyakarta State University Sports Hall. Participants who attended were 61 people. Participants were quite enthusiastic during the question and answer time, because it was related to the experience of using traditional medicine. Before the speaker starts delivering the material, the speaker first asks the participants about the habits of using traditional medicine. It turns out that there are still some habits that are not in accordance with the guidelines for the correct and safe use of traditional medicine. In the discussion session, it was seen that the
\end{abstract}


participants had increased their knowledge about how to use traditional medicines correctly and safely. They become more careful in consuming traditional medicine. The conclusion is that health education activities on guidelines for the use of traditional medicines can increase public knowledge about how to use traditional medicines properly.

Key words: health education, traditional medicine

\section{PENDAHULUAN}

Di dalam gaya hidup sehat modern yang berkembang saat ini, jamu dan obat tradisional tetap menjadi salah satu pilihan bagi masyarakat Indonesia. Masyarakat di pedesaan dan perkotaan pun mulai mengkonsumsi obat-obatan tradisional ini. Masyarakat Indonesia masih percaya pada obat tradisional ini. Hal itu bisa dilihat dari masih banyaknya penjual berbagai produk obat tradisional yang beredar di pasaran.

Banyaknya penggunaan obat tradisional di Indonesia berhubungan pula dengan banyaknya jenis tumbuhan di negeri ini. Indonesia tercatat sebagai salah satu negara yang memiliki kekayaan tumbuhan yang beragam. Keragaman obat tradisional di tanah air, telah memperkaya khazanah ilmu pengetahuan dan kesehatan bangsa Indonesia. Jamu dan obat tradisional, telah menjadi bagian yang tidak terpisahkan dari kehidupan masyarakat Indonesia (Sukmono, 2009).

Gaya hidup sehat yang berkembang saat ini, mengarahkan masyarakat untuk kembali menggunakan obat bahan alam. Jamu dan obat tradisional dapat menjadi salah satu pilihan pengobatan (Republik Indonesia, 1992). Presiden Republik Indonesia ke-6, Susilo Bambang Yudhoyono, memberikan perhatian khusus pada jamu dan obat tradisional dalam Pembukaan Musyawarah Nasional ke-5 Gabungan Pengusaha Jamu dan Obat Tradisional Indonesia.

Namun, apakah obat yang dibuat dari bahan-bahan alami ini sudah pasti benar dan aman untuk dikonsumsi? Pada dasarnya obat tradisional yang beredar di Indonesia aman untuk dikonsumsi, dengan catatan bahwa produk tersebut sudah terdaftar di BPOM RI (Anonim, 2014).

Melalui kegiatan ini, diharapkan terjadi peningkatan pengetahuan masyarakat tentang cara penggunaan obat tradisional yang benar dan aman serta masyarakat dapat melakukan swamedikasi obat tradisional dengan benar dan rasional. Swamedikasi yaitu penggunaan obat tanpa konsultasi dari dokter, diagnosa, serta peresepannya (Untari 2017). 


\section{MASALAH}

1) Apakah penyuluhan kesehatan tentang panduan penggunaan obat tradisional dapat meningkatkan pengetahuan masyarakat tentang cara penggunaan obat tradisional yang benar dan aman?

2) Apakah setelah mengikuti penyuluhan kesehatan ini, masyarakat dapat melakukan swamedikasi obat tradisional dengan benar dan rasional?

\section{METODE}

Jenis kegiatan ini adalah penyuluhan kesehatan. Peserta terdiri dari jamaah pengajian Masjid Baiturrahman Bantulan, Janti. RT 01, RW 01, Caturtunggal, Kec. Depok. Kabupaten Sleman. DI. Yogyakarta. Kegiatan ini dilaksanakan pada hari Sabtu tanggal 3 Agustus 2019, pukul 09.00 - 11.30. Tempat pelaksanaan di panggung utama Islamic Book Fair, GOR Universitas Negeri Yogyakarta. Metoda kegiatan penyuluhan kesehatan ini dengan menggunakan:

\section{1) Penyuluhan/Presentasi}

Narasumber menyampaikan pokok pokok panduan penggunaan obat tradisional meliputi cara memilih dan menggunakan obat tradisional yang benar dan aman. Dari materi ini, diharapkan masyarakat dapat melakukan swamedikasi dengan benar dan rasional.

\section{2) Tanya Jawab}

Dalam kegiatan penyuluhan kesehatan ini, peserta diberi kesempatan untuk bertanya dan berdiskusi dengan nara sumber.

\section{3) Evaluasi}

Untuk mengetahui perubahan pengetahuan peserta, narasumber melakukan tanya jawab sebelum dan sesudah presentasi. Tanya jawab sebelum presentasi bertujuan untuk menggali tentang kebiasaan peserta dalam penggunaan obat tradisional. Kemudian setelah presentasi, dilakukan tanya jawab kembali, bertujuan untuk melihat pemahaman peserta tentang cara penggunaan obat tradisional yang benar dan aman. 


\section{HASIL DAN PEMBAHASAN}

\section{1) Hasil}

Kegiatan ini bersamaan dengan acara Islamic Book Fair di GOR UNY. Peserta yang hadir dari jamaah pengajian Masjid Baiturrahman Bantulan, Janti. RT 01, RW 01, Caturtunggal, Kec. Depok. Kabupaten Sleman. DI. Yogyakarta dan pengunjung Islamic book fair.

Acara dimulai dengan pembukaan dan materi dari narasumber selama 60 menit. Narasumber menyampaikan pokok-pokok panduan penggunaan obat tradisional meliputi cara memilih dan menggunakan obat tradisional yang benar. Kemudian dilanjutkan dengan tanya jawab. Peserta diberi kesempatan untuk bertanya dan berdiskusi dengan nara sumber.

Sebelum narasumber memulai menyampaikan materi, nara sumber terlebih dahulu memberikan pertanyaan ke peserta tentang kebiasaan penggunaan obat tradisional. Ternyata masih ada beberapa kebiasaan yang tidak sesuai dengan pedoman penggunaan obat tradisional yang benar dan aman yaitu:

a. Peserta terkadang membeli obat tradisional yang belum terdaftar di BPOM RI. Misalnya membeli obat tradisional rajangan di pasar Beringharjo, belum ada ijin BPOM. Obat tradisional rajangan tersebut adalah sediaan obat tradisional berupa potongan simplisia, campuran simplisia, atau campuran simplisia dengan sediaan galenik, yang penggunaannya dilakukan dengan pendidihan atau penyeduhan dengan air panas.

b. Beberapa peserta tidak terbiasa mengikuti petunjuk pemakaian beserta dosis yang tercantum di kemasan. Mereka mengkonsumsi obat tradisional berdasarkan kebiasaan.

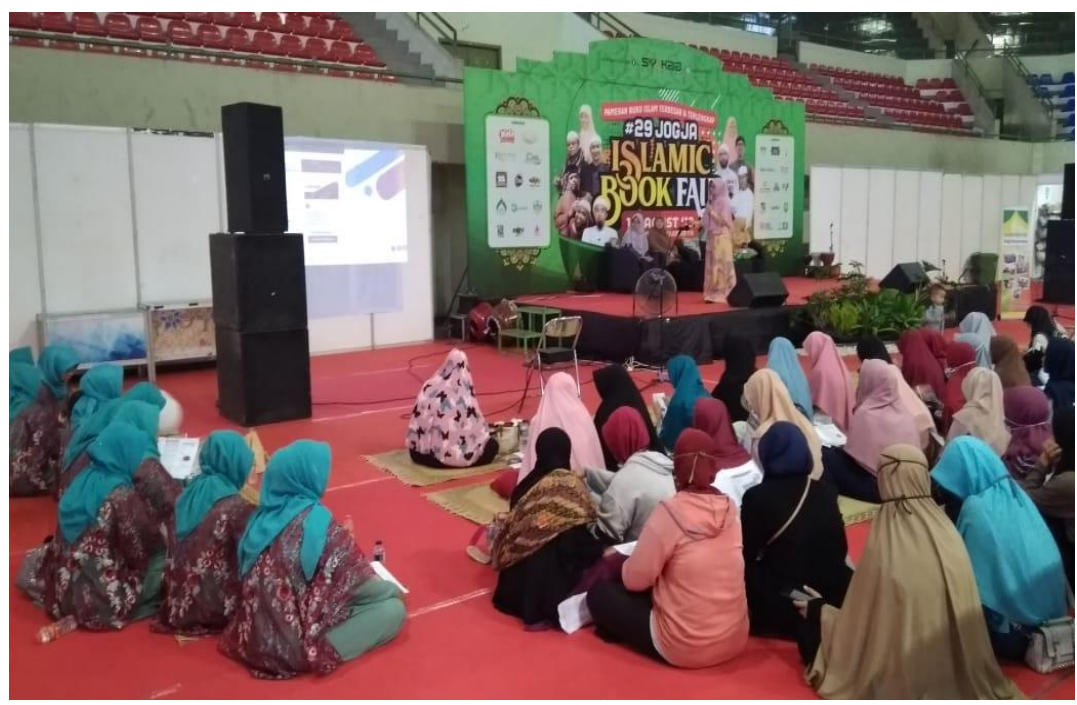

Gambar 1. Peserta antusias mencatat presentasi dari pembicara 


\section{2) Pembahasan}

Pada saat sessi ceramah, narasumber menyampaikan pokok-pokok panduan penggunaan obat tradisional meliputi cara memilih dan menggunakan obat tradisional yang benar dan aman. Dari materi ini, diharapkan peserta dapat melakukan swamedikasi dengan obat tradisional dengan benar dan rasional.

Narasumber menegaskan ke peserta untuk selalu membeli produk obat tradisional yang telah terdaftar di BPOM RI. Obat tradisional yang dikonsumsi harus terdaftar di Badan POM, supaya memberikan rasa benar dan aman. Obat tradisional illegal itu tidak punya ijin edar dari Badan POM, sehingga tidak dijamin mutu kesehatannya dan tidak benar dan aman untuk dikonsumsi. Jika ingin membeli obat tradisional harus sudah terdaftar di Badan POM dan ada izin edarnya (Republik Indonesia, 2019).

Saat sessi tanya jawab, peserta cukup antusias pada waktu diskusi, karena terkait dengan pengalaman swamedikasi yang mereka lakukan selama ini. Di sessi tanya jawab ini, terlihat kalau peserta sudah meningkat pengetahuannya tentang cara penggunaan obat tradisional yang benar dan aman. Mereka semakin berhati-hati dalam mengkonsumsi obat tradisional.

Peserta menanyakan tentang bagaimana aturan jika minum obat tradisional bersamaan dengan obat dari resep dokter. Narasumber menjelaskan jika minum obat tradisional bersamaan dengan obat dari resep dokter akan menimbulkan interaksi atau reaksi negatif jika dikonsumsi bersamaan. Jika ingin mengkonsumsi obat tradisional dan obat dari dokter, sebaiknya diberi jarak waktu minimal 3 jam. Dan masih banyak pertanyaan yang lannya, seputar masalah obat tradisional.

Diskusi ditutup dengan rangkuman oleh Narasumber, menekankan kembali tentang pedoman penggunaan obat tradisional yang benar dan aman dan memberikan pesan-pesan untuk memperkuat dampak intervensi supaya peserta mampu melakukan swamedikasi obat tradisional dengan benar dan rasional

\section{KESIMPULAN}

1) Kegiatan penyuluhan kesehatan tentang panduan penggunaan obat tradisional dapat meningkatkan pengetahuan masyarakat tentang cara penggunaan obat tradisional yang benar.

2) Setelah mengikuti penyuluhan kesehatan ini, peserta dapat melakukan swamedikasi obat tradisional dengan benar dan rasional. 


\section{DAFTAR PUSTAKA}

Anonim. (2014). Pedoman Rasionalisasi Komposisi Obat Tradisional Volume 1. Direktorat Obat Asli Indonesia, BPOM RI.

Republik Indonesia. (1992). Undang-Undang RI No. 23 tentang Kesehatan.

Republik Indonesia. (2019). Peraturan Badan Pengawas Obat dan Makanan Nomor 32 tentang Persyaratan Keamanan dan Mutu Obat Tradisional.

Sukmono. (2009). Mengatasi Aneka Penyakit Dengan Terapi Herbal. Agromedia Pustaka. 